\title{
Anti-TNF tedavilerin tetiklediği otoimmünite
}

\section{Anti-TNF therapy-induced autoimmunity}

\author{
Songül Çildağ ${ }^{1} \quad$ Taşkın Şentürk $^{1} \quad$ Berna Gültekin $^{2} \quad$ Gökhan Sargın $^{1}$ \\ ${ }^{1}$ Adnan Menderes Üniversitesi Tıp Fakültesi, İç Hastalıkları Anabilim Dalı, Aydın, Türkiye \\ ${ }^{2}$ Adnan Menderes Üniversitesi Tıp Fakültesi, Tıbbi Mikrobiyoloji Anabilim Dalı, Aydın, Türkiye
}

\section{Öz}

Amaç: Anti-TNF tedaviler günümüzde romatizmal hastalıkların tedavisinde etkin olarak kullanımaktadır. Kullanımının artması ve uzun sürekli takiplerde tedavi ile ilişkili bazı yan etkiler de ortaya çıkmaktadır. Bu yan etkilerden birisi de otoimmünite gelişimidir. Bu çalışmanın amacı romatizmal hastalıkları nedeniyle anti-TNF tedavi alan hastalarda otoimmünite gelişim sıklığını belirlemektir.

Gereç ve Yöntem: Çalışmaya romatoid artrit ve ankilozan spondilit hastalıkları nedeniyle anti-TNF tedavi almakta olan 67 hasta dahil edildi. Otuz iki hasta romatoid artrit, 35 hasta ankilozan spondilit idi. Otuz beş hasta infliximab, 16 hasta adalimumab, 16 hasta etanercept almaktaydı. Hastalık gruplarına ve anti-TNF tiplerine göre hastalar gruplara ayrıldı. ANA ve anti-dsDNA immünfloresan metodla, ACA ise ELISA yöntemi ile çalışıldı.

Bulgular: ANA pozitifliğinde anti-TNF tedavi öncesi \%10.4 iken, tedavi sonrasında \%40.3 olarak anlamlı bir artış tespit edildi. Yalnızca bir hastada anti-dsDNA pozitifliği saptandı. ACA ise hastaların hiçbirinde pozitif değildi. Diğer iki anti-TNF'ye kıyasla ANA pozitifleşmesi infliximab kullanan hastalarda belirgindi. ANA pozitifliği saptanan hastaların hiçbirinde lupusa ait klinik mevcut değildi. ANA pozitifleşmesi ile anti-TNF tedavi ile birlikte kullanılan metotrexat ve kortikosteroid kullanımı arasında, romatizmal hastalık tipi arasında bir ilişki saptanmadı.

Sonuç: Anti-TNF tedaviler, otoantikor gelişimini belirgin olarak arttırmaktadır. Ancak anti-TNF tedavilerin tetiklediği lupus gelişimi nadirdir.

Anahtar Sözcükler: Anti-TNF tedavi, otoimmünite.

\section{Abstract}

Aim: Anti-TNF therapy has recently emerged as an effective therapy for treating rheumatic diseases. With this increasing use and longer follow-up periods of treatment, various adverse effects are emerging. These adverse effects also include autoimmune processes. The aim of this study was to determine the autoimmune processes after anti-TNF therapy for rheumatic diseases.

Materials and Methods: This study included 67 patients who were treated with anti-TNF drugs for rheumatoid arthritis and ankylosing spondylitis. Thirty-two patients with rheumatoid arthritis and thirty-five patients with ankylosing spondylitis were monitered. Thirty-five patients receiving infliximab, sixteen patients receiving adalimumab, sixteen patients receiving etanercept. According to the rheumatic diseases groups and anti-TNF therapies groups, the patients were divided into subgroups. The ANA and anti-dsDNA antibody levels were identified by the immunefluorescence method and ACA antibody levels were identified by the ELISA methods.

Results: In this study, the percentages of ANA positivity in sixty-seven patients range from $10.4 \%$ to $40.3 \%$. Only one patient had serum level of anti-dsDNA. No patient had serum level of ACA. ANA induction was more important under infliximab than with the two other anti-TNF blockers. No patient developed clinical symptoms of lupus who had been seroconversion of antibody. ANA was not influenced by the underlying rheumatism or anti-TNF combined therapies with methotrexate and corticosteroids.

Conclusion: Anti-TNF induced autoantibodies are common following therapy with all of the currently available antiTNF therapies. However the incidence of anti-TNF inducel lupus is rare.

Keywords: Anti-TNF therapy, autoimmunity.

\footnotetext{
Yazışma Adresi: Songül Çildağ

Adnan Menderes Üniversitesi Tıp Fakültesi, i̇ç Hastalıkları

Anabilim Dalı, Aydın, Türkiye

Geliş Tarihi: 02.10.2015 Kabul Tarihi: 17.11.2015
} 


\section{Giriş}

Tümör nekroz faktör alfa (TNF- $\alpha$ ), T hücre aracılı doku hasarına neden olan inflamasyonda rol alan önemli bir sitokindir. TNF- $\alpha$ inhibisyonu yapan ilaçlar (anti-TNF) birçok romatizmal ve otoimmün hastalığın tedavisinde etkin olarak kullanılmaktadır. TNF- $\alpha$ inhibisyonu yapan ilaçların hepsi rekombinan proteinlerdir. İnfliximab ve adalimumab anti-TNF- $\alpha$ antikorları iken, etanercept TNF- $\alpha$ p75 reseptörü ile insan IgG1 Fc kısmının füzyon proteininden oluşmuştur $(1,2)$.

Kabul edilebilir düzeyde güvenilirliği ve tolerabilitesi olan bu ilaçların kullanımı sırasında gelişebilen yan etkiler arasında enfeksiyonlar, cilt kanseri, demyelinizan hastalıklar, kalp yetmezliğinde kötüleşme sayılabilir. Diğer önemli bir yan etki ise anti-TNF ilaç kullanımına bağlı otoimmünite gelişimi olup, asemptomatik immünolojik değişikliklerden yaşamı tehdit eden sistemik otoimmün hastalıklara kadar değişebilen geniş bir yelpaze oluşturur (3-6). Şimerik moleküler yapıya sahip olması nedeniyle infliximab kullanımında belirgin olmak üzere her üç tip anti-TNF kullanımında da otoantikorlar gelişebilmektedir (7-9). Bu otoantikorlar içerisinde antinükleer antikorlar (ANA) başta olmak üzere antifosfolipid antikorlar, antinötrofilik sitoplazmik antikorlar (ANCA), organ spesifik otoimmün hastalıklarla ilişkili otoantikorlar gibi farklı otoantikorlar yer almaktadır (10). Anti-TNF ilaç kullanımına bağlı gelişebilen otoimmün hastalıklar ise çoğunlukla olgu raporlarına dayanmaktadır. Hastalığın klinik belirtileri ve tedavisine ilişkin bilgiler sınırıdır.

Bu çalışmada, romatoid artrit (RA) ve ankilozan spondilit (AS) hastalıkları nedeniyle kliniğimizde takip edilmekte olup anti-TNF tedavi alan olgularımızda ANA, antidouble stranded DNA (çift sarmallı DNA, anti-dsDNA), antikardiyolipin antikor (ACA) düzeylerine bakarak antiTNF tedavi ile ilişkili otoimmünite ve otoimmün hastalık gelişme sıklığını, kullanılan anti-TNF ilaç ve hastalık tipi ile ilişkisini saptamayı amaçladık.

\section{Gereç ve Yöntem}

Çalışmaya romatoid artrit ve ankilozan spondilit hastalıkları nedeniyle anti-TNF ajan kullanan 35'i kadın 32 'si erkek toplam 67 hasta dahil edildi. Çalışma için etik kurul onayı ve hastalardan aydınlatılmış onamlar alındı. Hastaların anamnezleri alınıp, fizik muayeneleri yapıldıktan sonra dosya bilgileri incelendi. Hastaların cinsiyet, yaş, tanı, tanı süresi gibi demografik özellikleri ile kullanmakta oldukları anti-TNF ajan tipi, anti-TNF tedavi süresi, anti-TNF tedavi ile birlikte metotrexat ve kortikosteroid kullanıp kullanmadıkları, anti-TNF tedavi öncesi mevcutsa ANA, anti-dsDNA, ACA-IgM ve IgG düzeyleri kayıt edildi. Anti-TNF tedavi öncesi mevcut olan antikor düzeyleri ile tedavi sonrası antikor düzeylerini karşılaştırmak amacıyla hastalardan alınan kan örneklerinden ANA, anti-dsDNA IgG, ACA IgM ve IgG antikorları çalışıldı. Anti-TNF tedavinin otoantikor gelişimini arttırıp arttırmadığı, otoantikor gelişimi üzerine kullanılan anti-TNF ilaç tipinin, altta yatan hastalık tipinin, beraberinde MTX veya kortikosteroid kullanımının etkisinin olup olmadığı araştırıldı. Anti-TNF tedaviye bağlı ANA titrasyon düzeyleri ve ANA paterni belirlendi.

Antinükleer antikorlar (ANA) aynı kuyucukta Hep-20/10 ve karaciğer (maymun) dokusu içeren kit (Euroimmun, Almanya), dsDNA antikorları Crithidia luciliae içeren kit (Euroimmun, Almanya) kullanılarak indirekt floresan antikor yöntemi ile üretici firma önerilerine göre çalışıldı.

Serumlarda anti-kardiyolipin $\lg$ ve $\lg \mathrm{M}$ antikorları Enzyme Linked Immuno Sorbent Assay (ELISA) yöntemi ile üretici firma önerilerine göre (Euroimmun, Almanya) çalışıldı.

\section{Istatistiksel Analiz}

Verilerin istatistiksel olarak değerlendirilmesinde SPSS 13.0 programı kullanıldı. Elde edilen veriler ortalama \pm standart sapma ve yüzde olarak sunuldu. Niteliksel verilerin karşılaştırılması McNemar ki-kare, Pearson kikare, continuity correction ki-kare testleri ile yapıldı.

\section{Bulgular}

Yaşları 18 ile 69 arasında değişen (ortalama 47.13 \pm 13.02 ), 35’i kadın (\%52.2) 32'si erkek (\%47.8) toplam 67 hasta değerlendirildi. Hastalık süresi ortalama $120.01 \pm 89.77$ ay, hastaların almakta oldukları anti-TNF tedavi süresi ortalama $38.49 \pm 30.65$ ay idi. 67 hastanın 32'si RA ve 35'i AS idi (Tablo-1).

Tablo-1. Hastaların Demografik Özellikleri.

\begin{tabular}{lc}
\hline & Hasta sayısı (n=67) \\
\hline Kadın / erkek & $35 / 32$ \\
Ortalama yaş & $47.13 \pm 13.02$ \\
Hastalık süresi (ay) & $120.01 \pm 89.77$ \\
Anti-TNF tedavi süresi (ay) & $38.49 \pm 30.65$ \\
Hasta sayısı (RA) & 32 \\
Hasta sayısı (AS) & 35 \\
\hline
\end{tabular}

Tedavide kullanılan Anti-TNF ilaç tipleri; 35 hastada infliximab (\%52.2), 16 hastada adalimumab (\%23.9), 16 hastada etanercept, hastalık gruplarına göre anti-TNF ilaç tipleri sırasıyla RA'da 17 (\%53.2), AS'de 18 (\%51.4) infliximab, RA'da 8 (\%25), AS'de 8 (\%22.8) adalimumab, RA'da 7 (\%21.8), AS'de 9 (\%25.8) etanercept şeklinde idi. Gerek RA'da gerekse AS'de en fazla kullanılan ajan infliximab olmakla birlikte adalimumab ve etanercept kullanım oranları birbirine oldukça yakındı.

ANA pozitiflik oranları; toplam 67 hastanın tedavi öncesinde 7'sinde (\%10.4) ANA pozitifliği mevcutken tedavi sonrasında 27 hastada (\%40.3) ANA pozitifliği saptandı. Anti-TNF tedavinin anlamlı olarak ANA pozitifliğine neden olduğu tespit edildi $(p<0.001)($ Tablo-2). 
Tablo-2. Anti-TNF Öncesi ve Sonrası ANA Değerlerinin Karşılaştırması.

\begin{tabular}{ccccc}
\hline & $\begin{array}{c}\text { Anti-TNF } \\
\text { sonrası } \\
\text { ANA (-) }\end{array}$ & $\begin{array}{c}\text { Anti-TNF } \\
\text { sonrası } \\
\text { ANA (+) }\end{array}$ & Toplam & $\mathbf{p}^{*}$ \\
\hline $\begin{array}{c}\text { Anti-TNF } \\
\text { öncesi }\end{array}$ & 39 & 21 & 60 & \\
ANA (-) & & & & $<0.001$ \\
$\begin{array}{c}\text { Anti-TNF } \\
\text { Öncesi }\end{array}$ & 1 & 6 & 7 & \\
ANA (+) & & & & \\
\hline Toplam & 40 & 27 & 67 & \\
\cline { 1 - 2 } &
\end{tabular}

*: McNemar ki-kare testi.

Tedavi öncesi RA'da 7 hastada ANA (\%22) pozitif iken tedavi sonrası 18 hastada (\%56), AS'de ise hastaların hepsinde tedavi öncesi ANA negatif iken tedavi sonrası 9 hastada (\%26) ANA pozitifliği saptandı. ANA pozitifleşme oranlarının hastalık tipi ile anlamlı bir ilişkisi olmadığı gözlendi $(p=0,083)$.

Anti-TNF ilaç tiplerine göre ANA pozitifliği karşılaştırıldığında; tedavi öncesi infliximab kullanan 2 hastada (\%6) ANA pozitif iken, tedavi sonrası 18 hastada (\%51), adalimumab kullanan 3 hastada (\%19) ANA pozitif iken tedavi sonrası 4 hastada (\%25), etanercept kullanan 2 hastada (\%13) ANA pozitif iken tedavi sonrası 5 hastada (\%31) ANA pozitifliği saptandı. Yeni oluşan ANA pozitiflik oranları, infliximab kullanımında anlamlı olarak daha yüksek saptandı $(p=0,040)($ Tablo-3).

Tablo-3. Anti-TNF İlaç Tiplerinin ANA Pozitiflik Oranlarına Etkisinin Karşılaştırması.

\begin{tabular}{lcc}
\hline & $\begin{array}{c}\text { Anti-TNF öncesi } \\
\text { ANA (-) } \\
\text { Anti-TNF sonrası } \\
\text { ANA (-) }\end{array}$ & $\begin{array}{c}\text { Anti-TNF öncesi } \\
\text { ANA (-) } \\
\text { Anti-TNF sonrası } \\
\text { ANA (+) }\end{array}$ \\
\hline Infliximab & 17 & 16 \\
Adalimumab & 12 & 2 \\
Etanercept & 11 & 3 \\
\hline
\end{tabular}

Anti-TNF tedavi ile birlikte kullanılan MTX ve kortikosteroidlerin tedavi sonrası ANA pozitifleşmesi üzerine etkisi incelendiğinde; ANA'sı negatif olan MTX kullanmayan 38 hastadan 10'unda, MTX kullanan 23 hastadan 11 tanesinde tedavi sonrası ANA pozitifliği saptandı. Anti-TNF tedavi ile birlikte ANA'sı negatif olan kortikosteroid kullanmayan 42 hastadan 12'sinde, kortikosteroid kullanan 19 hastadan 9'unda tedavi sonrası ANA pozitifliği saptandı. MTX ve kortikosteroid kullanımının Anti-TNF tedavi sonrası oluşan ANA pozitifliğine anlamlı bir etkisinin olmadığı gözlendi $(p=0.151 ; p=0.254)$ (Tablo-4).

Anti-TNF tedavi sonrasında yeni oluşan ANA'sı (+) 21 hastanın 20'sinde homojen patern, 1 'inde granüler patern saptandı. Hastaların 17'sinde ANA titrasyonu 1/100, 4'ünde ise $1 / 320$ idi. Tedavi ile ilişkili en sık homojen paternde ve 1/100 titrasyonda ANA pozitifliği saptandı.
Tablo-4. MTX ve Kortikosteroid Kullanımının Anti-TNF Tedavi Sonrası ANA (+)'liği İle İlişkisi

\begin{tabular}{cccc}
\hline & $\begin{array}{c}\text { Anti TNF öncesi } \\
\text { ANA (-) } \\
\text { Anti-TNF } \\
\text { sonrası ANA (-) }\end{array}$ & $\begin{array}{c}\text { Anti TNF öncesi } \\
\text { ANA (-) } \\
\text { Anti-TNF } \\
\text { sonrası ANA (+) }\end{array}$ & p $^{*}$ \\
Metotrexate (-) & 28 & 10 & 0.151 \\
Metotrexate (+) & 12 & 11 & \\
Kortikosteroid (-) & 30 & 12 & 0.254 \\
Kortikosteroid (+) & 10 & 9 & \\
\hline
\end{tabular}

*: Continuity correction ki-kare testi.

Anti-TNF tedavi sonrasında ACA-IgM ve IgG düzeyleri hastaların hepsinde negatif, anti-dsDNA yalnızca bir hastada pozitifti.

\section{Tartışma}

Romatoid artrit ve prototipi ankilozan spondilit olan spondiloartropatiler (SPA) romatizmal hastalıklar içerisinde en sık görülen hastalık grubudur. Her iki hastalık grubunun ortalama prevalansı $\% 0.3$ civarındadır (11). Bu hastaların \%10-15 kadarı konvansiyonel tedavilere dirençli olup, hastalık aktif ve progresif seyretmektedir. $\mathrm{Bu}$ hastalarda hastalık sürecinin herhangi bir döneminde anti-TNF tedavi intiyacı doğmaktadır. Biyolojik ajanların gerek RA'da gerekse AS'de klinik aktiviteyi ve yapısal hasarı düzeltmede oldukça etkin olduğu bilinmektedir $(7-9,12,13)$.

Anti-TNF tedavilerin kullanımı ile birlikte, bu tedavilerin otoantikor gelişimini tetiklediği gösterilmiştir. Şimerik moleküler yapıya sahip olması nedeniyle infliximab kullanımında belirgin olmak üzere, her üç tip anti-TNF kullanımında da otoantikorlar gelişebilmektedir (7-9). Bu otoantikorlar içerisinde ANA başta olmak üzere antifosfolipid antikorlar, antinötrofilik sitoplazmik antikorlar (ANCA), organ spesifik otoimmün hastalıklarla ilişkili otoantikorlar gibi farklı otoantikorlar yer almaktadır (10).

Anti-TNF ajanlar arasında kıyaslamalı ilk çalışma Eriksson ve ark. (14) tarafından yapılmış olup, infliximab ve etanercept kullanan RA'lı hastalardan yalnızca infliximab kullanan grupta ANA pozitifliği saptanmıştır. Bu çalışmada ANA pozitifliği infliximab sonrası \%24'ten \%69'a çıkmıştır. Daha sonra yapılan çalışmalarda da RA'lı ve SPA'ı hastalarda anti-TNF ilişkili ANA pozitifliği olduğunu ve ANA pozitifliğinin her iki hasta grubunda da infliximab kullanımına bağlı olduğunu göstermiştir (1517).

Benzer çalışmalarda da ANA pozitifliğinin her iki hastalık gurubunda da özellikle infliximab kullanımı ile ilişkili olduğu gözlenirken daha az sıklıkla olmak üzere sırasıyla adalimumab ve etanercept kullanımın da geliştiği gösterilmiştir. İnfliximab kullanan hastalarda bu kadar yüksek oranda ANA pozitifliğine rağmen çoğunlukla bağ dokusu hastalığı ile ilişkilendirilebilecek klinik bulgular gözlenmemiştir $(10,14,17-20)$. Biz de 
çalışmamızda ANA pozitifliğinin anti-TNF tedavi ile $\% 10.4$ 'ten \%40.3'e yükseldiğini, anti-TNF tedavinin anlamlı olarak ANA pozitifliğine neden olduğunu gözlemledik $(p<0.001)$. Çalışmamızda literatürle uyumlu olarak en sık infliximab kullanan hastalarda ANA pozitifliği saptadık $(p=0.049)$. ANA pozitifliğinin daha az sıklıkla sırasıyla etanercept ve adalimumab kullanan hastalarda da gözlendiğini ancak anlamlı bir artışa neden olmadığını tespit ettik. Bunu açıklayan bazı hipotezler mevcuttur. Bunlardan birisi her ikisinin de monoklonal antikor olmasına rağmen infliximabın yapısının şimerik, adalimumabın ise insan monoklonal antikoru olmasıdır. Etanerceptte ise diğerlerinden farklı olarak IgG'nin Fc kısmına TNFR2'nin hücre dışı parçası füzyon proteini olarak eklenmiştir. Bu yapısal farklılık nedeni ile etanercept ve infliximabın farklı $T$ hücre fonksiyonlarını etkilediği düşünülmektedir. Etanercept artmış IF- $\mathrm{Y}$ üretimini sağlarken IL-4, IL-10 seviyelerini etkilemez. İnfliximab ise IL-2, IF- $Y$ gibi Th1 tipi sitokin üretimini azaltırken, IL-4, IL-10 gibi Th2 tipi sitokin üretimini artırır. Böylece otoantikor üretimine neden olabilmektedir $(14,21,22)$. Diğer bir hipotez; transmembranöz TNF- $\alpha$ aktivitesinin bloke edilmesidir. Şimerik yapıda bulunan infliximab yalnızca soluble TNFa'yı değil aynı zamanda transmembranöz TNF-a'yı da güçlü bir şekilde inhibe eder. Transmembranöz TNFa'nın anti-TNF ilaçlarla bağlanması hücre apopitozisine ve dolayısıyla otoantijenlerin açığa çıkmasına neden olur. Böylece otoantikor gelişimi tetiklenir (23). Etanerceptin asıl olarak soluble TNF-a'yı bloke etmesi nedeniyle infliximab kullanımında gelişen $T$ lenfosit ve monositlerdeki apopitozis etanercept kullanımında gözlenmez. İnfliximab'a benzer şekilde adalimumab kullanımında da periferik kan monositlerinde apopitozis gözlenir. Etanercept ile monoklonal antikorların farklı mekanizma ile TNF-a'yı bloke etmesi otoantikorların infliximab kullanımında neden daha fazla olduğunu açıklamaktadır. Diğer bir hipoteze göre ise; anti-TNF tedavi ile fizyolojik olarak otoreaktif $\mathrm{B}$ hücrelerini inhibe eden $\mathrm{T}$ sitotoksik hücrelerde fonksiyon kaybı olması böylece $B$ hücreler üzerindeki süpresyonun ortadan kalkması otoantikor gelişimini uyarmaktadır (24). ANA sentezi plazmasitoid dentritik hücreler tarafından salınan IFN- $\alpha$ sentezine bağlıdır. TNF- $\alpha$ 'nın bloke edilmesi ile dentritik hücrelerde proliferasyon gelişir ve IFN- $\alpha$ sentezi artar. Lupus gelişiminde rolü iyi bilinen artmış IFN- $\alpha$ sentezi de plazmositlerden ANA sentezini indükler (21).

Çalışmamızda ayrıca, ANA pozitifliği olan hastaların hiçbirinde lupusa ait klinik belirti ve bulgu saptamadık.

Yapılan çalışmalarda daha spesifik bir otoantikor olan anti-dsDNA pozitifliğine bakıldığında her üç tip anti-TNF kullanımında da oldukça düşük oranda (\%5-15) anti-ds DNA pozitifliği bildirilmiştir. Düşük oranda pozitifleşebilen anti-dsDNA'nın çoğunlukla lupusun kliniğiyle ilişkili olmadığı gözlenmiştir (25). Biz de çalışmamızda yalnızca bir hastada anti-TNF tedaviye bağlı anti-dsDNA IgG pozitifliği saptadık ve bu hastada da lupusla ilişkili herhangi bir klinik mevcut değildi. Bu nedenle anti-TNF tedavilerin özellikle lupus için anlamlı olan anti-dsDNA IgG pozitifliği üzerine belirgin bir etkisi olmadığını düşündük.

Yapılan çalışmalarda hastalık grupları arasında otoantikor gelişimi açısından bir fark gözlenmemiş ve otoantikor oluşumunda altta yatan hastalıktan çok antiTNF'lerin asıl rolü olduğu düşünülmüş (26). Bizim çalışmamızda da gerek RA, gerekse AS gurubunda otoantikor gelişimi üzerine hastalık açısından bir farklılık gözlenmedi $(p=0.083)$. Bu nedenle ANA pozitifliğinin hastalık tipinden ziyade kullanılan anti-TNF ilaçlara bağlı olduğunu düşündük.

Anti-TNF ilaçlarla birlikte kullanılan MTX veya kortikosteroidlerin ANA ve anti-dsDNA oluşumunda etkili olup olmadığı tartışmalıdır. De Rycke ve ark. (18), antiTNF ile kombine MTX kullanımında otoantikor gelişimini daha az gözlerken, Bacquet-Deschryver ve ark. (26) ile Ferraro-Peyret ve ark. (10), MTX veya kortikosteroid kullanımının otoantikor gelişimine herhangi bir etkisi olmadığını bildirmiştir. Bizim çalışmamızda gerek MTX kullanımının gerekse kortikosteroid kullanımının otoantikor gelişimine bir etkisi olmadığını gözlemledik. $(p=0.151$ ve $p=0.254)$.

Çalışmamızda ayrıca anti-TNF sonrası yeni oluşan ANA paternleri incelendiğinde 21 hastadan 20' sinde homojen patern ve sadece birinde granüler patern saptadık. Literatürle uyumlu olarak biz de çalışmamızda en sık homojen paternde ANA pozitifliği olduğunu gözlemledik (27). ANA titrasyonları açısından bakıldığında De Rycke ve ark. (17), anti-TNF kullanımının ANA titrasyonunda artışa neden olduğunu, infliximab kullanan hastaların $\% 61.8$ 'inde, etanercept kullananların ise \%5'inde titrasyonda belirgin artı̧̧ olduğunu göstermiş. BacquetDeschryver ve ark. (26) da infliximab kullanımında ANA titrasyonunun belirgin artığını, adalimumab ve etanerceptte ise daha az sıklıkla olmak üzere ANA titrasyonlarında artış olduğunu göstermiştir. Çalışmamızda ise ANA testi tedavi öncesi pozitif olan 7 hastadan 4'ünde titrasyonda bir değişiklik gözlenmedi, bir hastada titrasyonda azalma, bir hastada titrasyonda artış, bir hastada ise ANA'nın negatifleştiği gözlendi. Titrasyonda artış gözlenen bir hasta ise adalimumab kullanmakta idi. Sonuç olarak anti-TNF kullanımı ile ANA titrasyonunda bir artış gözlemlemedik.

Anti-TNF kullanımına bağlı antifosfolipid antikor üretimi ile ilişkili sınırlı veri bulunmaktadır. Çelişkili sonuçlar olmakla birlikte Elliot ve ark. (28), anti-TNF kullanan 20 RA hastasından yalnızca bir tanesinde ACA pozitifliği saptamış. Ferraccioli ve ark. (29), etanercept kullanan hastalarda ACA gelişiminin birlikte görülen bakteriyel enfeksiyonlarla ilişkili olabileceğini antibiyotik tedavisi ile ACA titrelerinde azalma olduğunu göstermiş. Jonsdottir ve ark. (30) yaptıkları çalışmada, anti-TNF kullanımı ile (infliximab ve etanercept) ACA antikor gelişimi arasında ilişki olduğunu ve kötü klinik sonuçlara neden olduğunu 
tanımlamışken diğer iki çalışmada bu ilişki gösterilememiş $(28,29)$. Yine başka bir çalışmada adalimumab ile tedavi edilen RA'lı hastalarda ACA veya ß-2 glikoprotein1 beta oluşumu açısından bir ilişki gösterilememiş (31). Geniş hasta serileri ile yapılan çalışmalar sonucunda ACA titreleri takiplerde artmaya devam ederse ve trombotik olay eşlik ederse klinik olarak anlamlı kabul edilebileceği gösterilmiştir. Ancak anti-TNF kullanımı altında ACA tespit edilen hastalarda çok nadiren trombotik olay geliştiği bildirilmiştir (32). Çalışmamızda anti-TNF tedavi öncesi hiçbir hastada ACA düzeyleri bakılmamıştı. Tedavi sonrası ise hastaların hiçbirinde ACA IgM ve/veya IgG pozitifliği saptanmadı.

\section{Sonuç}

Araştırmamızda anti-TNF tedavinin ANA oluşumunu anlamlı olarak arttırdığı, anti-dsDNA IgG ve ACA IgM ve IgG oluşumunu etkilemediği saptandı. Anti-TNF ilaçlardan en sık infliximab kullanımında otoantikor geliştiği daha az sıklıkla ve birbirine benzer oranlarda etanercept ve adalimumab kullanımında da otoantikor gelişebildiği gösterildi. Ancak çalışmamızda hasta sayısının az olmasının özellikle etanercept ve adalimumab kullanan hasta sayısının az olmasının olası bir farkın gösterilmesini engellemiş olabileceği de düşünüldü. Otoantikor gelişiminde altta yatan hastalık tipinin önemli olmadığı, otoantikor gelişiminin anti-TNF tedaviye bağlı olduğu gözlendi. Ayrıca anti-TNF tedavi ile birlikte MTX veya kortikosteroid kullanımının otoantikor gelişimini etkilemediği gösterildi. Anti-TNF tedaviye bağlı oluşan ANA'nın sıklıkla homojen paternde olduğu ve genellikle 1/100 titrasyonda olduğu, oluşan otoantikorların tedaviye yanıtı etkilemediği gözlendi. Ayrıca otoantikor pozitifliği saptanan hastalarda lupusa ait hiçbir klinik belirti ve bulgu olmaması anti-TNF ilaçların otoimmün hastalıktan ziyade sadece otoimmünite gelişimini tetiklediğini düşündürdü.

\section{Kaynaklar}

1. Haraoui B. Differentiating the efficacy of the tumor necrosis factor inhibitors. Semin Arthritis Rheum 2005;34(5Suppl 1):7-11.

2. Nurmohamed MT, Dijkmans BA. Efficacy, tolerability and cost effectiveness of disease-modifying antirheumatic drugs and biologic agents in rheumatoid arthritis. Drugs 2005;65(5):661-94.

3. Genovese MC, Bathon JM, Fleischmann RM, et al. Long term safety, efficacy and radiographic outcomes with etanercept treatment in patients with early rheumatoid arthritis. J Rheumatol 2005;32(7):1232-42.

4. Lebwohl M, Gottlieb A, Wallis W, Zitnik R. Safety and efficacy of over 7 years of etanercept therapy in a global population of patients with rheumatoid arthritis. J Am Acad Dermatol 2005; 52(3): 195.

5. Haraouia B, Keystone E. Musculoskeletal manifestations and autoimmune diseases related to new biologic agents. Curr Opin Rheumatol 2006;18(1):96-100.

6. Rubin RL. Drug-induced lupus. Toxicology 2005;209(2):135-47.

7. Maini RN, St Clair EW, Breedveld F, et al. Infliximab (chimeric anti-tumour necrosis factor a monoclonal antibody) versus placebo in rheumatoid arthritis patients receiving concomitant methotrexate. A randomised phase III trial. Lancet 1999;354(9194):1932-9.

8. Van Der Heijde D, Klareskog L, Rodriguez-Valverde V, et al. Comparison of etanercept and methotrexate, alone and combined, in the treatment of rheumatoid arthritis: Two-year clinical and radiographic results from the TEMPO study, a double-bind, randomized trial. Arhritis Rheum 2006;54(4):1063-74.

9. Weinblatt ME, Keystone EC, Furst DE, et al. Adalimumab, a fully human anti-tumor necrosis factor alpha monoclonal antibody, for the treatment of rheumatoid arthritis in patients taking concomitant methotrexate: The ARMADA trial. Arhritis Rheum 2003;48(1):35-45.

10. Ferraro-Peyret C, Coury F, Tebib JG, Bienvenu J, Fabien N. Infliximab therapy in rheumatoid arthritis and ankylosing spondylitis-induced specific antinuclear and antiphospholipid autoantibodies without autoimmune clinical manifestations. A twoyear prospective study. Arhritis Res Ther 2004;6(6):535-43.

11. Pincus T. Longterm outcomes in RA. Br J Rheumatol 1995;34(Suppl2):59-73.

12. Moreland LW, Margolies G, Heck LW Jr, et al. Recombinant soluble tumor necrosis factor receptor (p80) fusion protein: Toxicity and dose finding trial in refractory rheumatoid arthritis. J Rheumatol 1996;23(11):1849-55.

13. Moreland LW, Baumgartner SW, Schiff MH, et al. Treatment of rheumatoid arthritis with a recombinant human tumor necrosis factor receptor (p75)-Fc fusion protein. N Engl J Med 1997;337(3):141-7.

14. Eriksson C, Engstrand S, Sundqvist KG, Rantapaa-Dahlqvist $S$. Autoantibody formation in patients with rheumatoid arthritis treated with anti-TNF- $\alpha$. Ann Rheum Dis 2005;64(3):403-7.

15. Allanore $Y$, Sellam J, Batteux F, et al. Induction of autoantibodies in refractory rheumatoid arthritis treated by infliximab. Clin Exp Rheumatol 2004;22(6):756-8.

16. Caramaschi P, Biasi D, Colombatti M, et al. Anti-TNF alpha therapy in rheumatoid arthritis and autoimmunity. Rheumatol Int 2006;26(3):209-14.

17. De Rycke L,Baeten D, Kruithof E, Van den Bosch F, Veys EM, De Keyser F. Infliximab but not etanercept, induced IgM antidouble stranded DNA autoantibodies as main antinuclear reactivity: Biological and clinical implications in autoimmune arthritis. Arthritis Rheum 2005;52(7):2192-201.

18. De Rycke L, Kruithof E, Van Damme N, et al. Antinuclear antibodies following infliximab treatment in patients with rheumatoid arthritis or spondylarthropathy. Arthritis Rheum 2003;48(4):1015-23.

19. De Rycke L, Baeten D, Kruithof E, Van den Bosch F, Veys EM, De Keyser F. The effect of TNF alpha blockade on the antinuclear antibody profile in patients with chronic arthritis: Biological and clinical implications. Lupus 2005;14(12):931-7. 
20. Sellam J, Allanore Y, Batteux F, Job Deslandre C, Weill B, Kahan A. Autoantibody induction in patients with refractory spondylarthropathy treeted with infliximab and methotrexate. Joint Bone Spine 2005;72(1):48-52.

21. Catrina AI, Trollmo C, af Klint E, et al. Evidence that anti-tumor necrosis factor therapy with both etanercept and infliximab induces apoptosis in macrophages, but not lymphocytes, in rheumatoid arthritis joints. Arthritis Rheum 2005;52(1):61-72.

22. Zou J, Rudwaleit M, Brandt J, Thiel A, Braun J, Sieper J. Up regulation of the production of tumour necrosis factor alpha and interferon gamma by T cells in ankylosing spondylitis during treatment with etanercept. Ann Rheum Dis 2003;62(6):561-4.

23. Charles PJ, Smeenk RJ, De Jong J, Feldmann M, Maini RN. Assessment of antibodies to double-stranded DNA induced in rheumatoid arthritis patients following treatment with infliximab a monoclonal antibody to tumor necrosis factor alpha; findings in opel-label and randomized placebo-controlled trials. Arhritis Rheum 2000;43(11):2383-90.

24. Via CS, Shustov A, Rus V, et al. In vivo neutralization of TNF-alpha promotes humoral autoimmunity by preventing the induction of CTL. J Immunol 2001;167(12):6821-6.

25. De Bandt M, Vittecog O, Deschamps V, Le Loet X, Meyer O. Anti-TNF alpha induced systemic lupus syndrome. Clin Rheumato 2003;22(1):56-61.

26. Bacquet-Deshryver $\mathrm{H}$, Jouen $\mathrm{F}$, Quillard $\mathrm{M}$, et al. Impact of three anti-TNFa biologics on existing and emergent autoimmunity in rheumatoid arthritis and spondylarthropathy patients. J Clin Immunol 2008;28(5):445-55.

27. Bobbio-Pallavicini F, Alpini $C$, Caporali $R$, et al. Autoantibody profile in rheumatoid arthritis during long-term infliximab treatment. Arthritis Res Ther 2004;6(3):264-72.

28. Elliott MJ, Maini RN, Feldmann M, et al. Treatment of rheumatoid arthritis with chimeric monoclonal antibodies to tumor necrosis factor-a. Arthritis Rheum 1993;36(12):1681-90

29. Ferraccioli G, Mecchia F, Di Poi E, Fabris M. Anticardiolipin antibodies in rheumatoid patients treated with etanercept or conventional combination therapy: Direct and indirect evidence for a possible association with infections. Ann Rheum Dis 2002;61(4):358-61.

30. Jonsdottir T, Forslid J, van Vollenhoven A, et al. Treatment with tumor necrosis factor alpha antagonists in patients with rheumatoid arthritis induces anticardiolipin antibodies. Ann Rheum Dis 2004;63(9):1075-8.

31. Fabiola A, Maurizio T, Franco C, Andrea D, Pierluigi M, Piercarlo SP. Autoimmunity and anti-TNF-a agents. Ann NY Acad Sci 2005;1051:559-69.

32. Nosbaum A, Goujon C, Fleury B, et al. Arterial thrombosis with anti-phospholipid antibodies induced by infliximab. Eur $J$ Dermatol 2007;17(6):546-7. 